\title{
Financial Inclusion Strategies: Progress in Dakshina Kannada District
}

\author{
Maria Rodrigues ${ }^{1}$, Dr. Suresh Poojary ${ }^{2}$ \\ ${ }^{1}$ Assistant Professor, Department of P.G Studies in Commerce, St. Aloysius College (Autonomous), Mangalore. \\ ${ }^{2}$ Associate Professor, Dean, Faculty of Commerce, St. Aloysius College (Autonomous), Mangalore.
}

\begin{abstract}
Indian economy has travelled a long path of economic development but the aftermaths show that benefits pertaining to this have hardly reached $50 \%$ of the Indian population mainly because of no access to loan and insurance. These factors necessitate the urgent need for financial inclusion. Financial inclusion revolves around deposit mobilization and credit intermediation to a wider section of population and is considered to be an integral part of inclusive growth process and sustainable development. Financial inclusion is believed to bring in socio economic impact on the lives of the vulnerable. Banks play a major role in providing various financial services. Irrespective of various supply side issues, in the recent past financial inclusion progress has been remarkable. Therefore this paper evaluates the strategies adopted in Dakshina Kannada District and the Progress of these strategies.
\end{abstract}

Keywords: Financial Inclusion, Poverty Reduction

\section{Introduction}

Financial development reduces income inequality and exerts a disproportionally positive impact on the bottom quintile (AurelieLarquemin, 2015). In the recent past, financial inclusion has emerged as the buzzword in the Indian financial system. In the zeal to drive the policy initiative in a mission mode, banks have collaborated with Business Correspondents to extend the formal banking services to regions and people who remained unbanked even after six decades of independence of the country(RBI Monthly Bulletin July, 2013). The process of financial inclusion plays a major role in driving a way the poverty from the country. Financial inclusion refers to delivery banking services to masses including privileged and disadvantaged people at an affordable and inexpensive terms and conditions. The three main facets of financial inclusion are (i) financial market accessibility (ii) credit market accessibility (iii) awareness of financial matters (Dr. NamitaRajput \&Ms Shelly Oberoi).

Meaningful financial inclusion hinges on four critical parameters (a) all adults in each family have an operative bank account through which regular credits and withdrawals take place; (b) providing small overdraft/credit facilities to the people who need it; (c) providing remittance services through the banks and (d) providing micro insurance through the banks (RBI Monthly Bulletin July ,2013).

In order to accelerate greater financial inclusion RBI and Government of India has implemented various strategies such as No frills accounts/Basic savings bank accountsavings and deposits, Overdraft facility in BSBA accounts, General credit cards, Kissan credit card, Micro-insurance, Credit -consumption and business, ICT accounts-BC, Selfhelp groups, financial literacy programmes and many more such initiatives. This paper evaluates some of these strategies to understand the progress of financial inclusion in Dakshina Kannada District.

\section{Objectives}

- To study the need and importance of financial inclusion.

- To analyse the progress of financial inclusion in India.

- To study the progress of financial inclusion in Dakshina Kannada District.

- To suggest steps for further implementation of financial inclusion strategies.

\section{Literature Review}

A growing number of randomized evaluations suggest that financial services do have a positive impact on a variety of microeconomic indicators, including self-employment business activities, household consumption, and wellbeing(AurelieLarquemin, 2015). Well-functioning financial systems serve a vital purpose, offering savings, credit, payment, and risk management products to people with a wide range of needs. Without inclusive financial systems, poor people must rely on their own limited savings to invest in their education or become entrepreneurs - and small enterprises must rely on their limited earnings to pursue promising growth opportunities. This can contribute to persistent income inequality and slower economic growth (CGAP, 2006).Greater access to financial services and increased incomes allow poor people to invest in their children's future.Access to financial services allows clients to seek health care services when needed, rather than wait until an illness has reached crisis proportions. The ability to borrow, save, and earn income enhances poor women's confidence, enabling them to better confront systemic gender inequities.(CGAP- Poor and Low-Income Clients, 2006).

However, the recent efforts taken by the commercial banks towards financial inclusion have been mostly associated with the opening of bank accounts for individuals who previously did not own one. A broader idea of financial inclusion should focus on increasing the productivity of vulnerable groups and ensuring sustainability in the long run. This means that banks should go beyond bank accounts and credit - they need to tap into savings and additional income to reduce risk and to help smoothen consumption, 


\section{International Journal of Science and Research (IJSR) \\ ISSN (Online): 2319-7064}

Index Copernicus Value (2013): 6.14 | Impact Factor (2014): 5.611

while simultaneously trying to increase asset values (Lakshmi Kumar and G. Balasubramanian,2015)A recent Reserve Bank Research Project Study titled How the Poor Manage their Finances: A Study of the Portfolio Choices of Poor Households in Ernakulam District, Kerala" has observed that meaningful financial inclusion of the poor by the commercial banks would critically depend on their ability to meet the credit gaps of the poor households.

The Reserve Bank expects the level of banking sector engagement at the grass-root level is increased and higher levels of economic \& financial activities through the banking system are facilitated even if it involves low-ticket business. This may provide more meaning to the spirit of financial inclusion than the statistics of financial inclusion (RBI Monthly Bulletin July, 2013).

\section{Recent Financial Inclusion Initiatives}

Learning from the experience gained from the outcomes of FI initiatives over the years, the Reserve Bank has taken certain additional steps to provide greater impetus to the process of financial inclusion.

- Banks are encouraged to adopt a structured and planned approach to financial inclusion with commitment at the highest levels, through preparation of Board approved Financial Inclusion Plans (FIPs). The first phase of FIPs was implemented over the period 2010- 2013. The Reserve Bank has sought to use the FIPs as the basis for FI initiatives at bank level through certain measures:

- Banks advised to prepare Board approved FIPs for the period 2013-2016.

- RRBs also advised to prepare comprehensive FIPs, consequent to their migration to CBS in 2011.

- In order to ensure closer monitoring of FI performance of bank branches, banks have been advised to disaggregate their FIPs up to controlling office and branch level.

- Structured, comprehensive monitoring mechanism put in place by the Reserve Bank for evaluating banks' performance against their FIP plans. Annual review meetings are being held with CMDs of banks to ensure top management support and commitment to the FI process.

- In the Annual Policy Statement for 2013-14, banks have been advised to consider frontloading (prioritising) the opening of branches in unbanked rural centres over a three year cycle co-terminus with their FIPs. This is expected to facilitate the branch expansion in unbanked rural centres.

- After successful achievement of the target of ensuring provision of banking services through a banking outlet in every village with population above 2000 by March 2012, SLBCs were advised to prepare a road map for provision of banking services in all unbankedvillages with population below 2000 in a timebound manner. Under the road map, SLBCs have identified about 4,85,000 unbanked villages with population less than 2000 and the same have been allotted to banks.

- An integrated approach has been adopted for achieving financial inclusion through financial literacy. Financial Literacy Centres and rural branches of scheduled commercial banks have been advised to conduct outdoor Financial Literacy Camps at least once a month.

- In order to ensure smooth roll out of the Government's Direct Benefit Transfer (DBT) initiative, banks have been advised to:

- Open accounts of all eligible individuals in camp mode with the support of local government authorities.Seed the existing and new accounts with Aadhaar numbers and put in place an effective mechanism to monitor and review the progress in implementation of DBT.

- Emphasis is on increasing the proportion of brick and mortar branches vis-a-vis BC outlets (RBI Monthly Bulletin July, 2013).

\section{Progress of Financial Inclusion}

\begin{tabular}{|l|c|c|c|c|}
\hline \multicolumn{1}{|c|}{ Particulars } & $\begin{array}{c}\text { Year } \\
\text { Ended } \\
2010\end{array}$ & $\begin{array}{c}\text { Year } \\
\text { Ended } \\
2013\end{array}$ & $\begin{array}{c}\text { Year } \\
\text { Ended } \\
2014\end{array}$ & $\begin{array}{c}\text { Progress } \\
2013- \\
2014\end{array}$ \\
\hline Total No. of Villages Covered & 67,694 & $2,68,454$ & $3,83,804$ & $1,15,350$ \\
\hline Villages covered through branches & 33,378 & 40,837 & 46,126 & 5,289 \\
\hline Villages covered through BC's & 34,316 & $2,27,617$ & $3,37,678$ & $1,10,061$ \\
\hline Basic savings Deposits A/C through branches (No. in Million) & 60.2 & 100.8 & 126.0 & 25.2 \\
\hline Basic savings Deposits A/C through branches (Amt. in Rs. Billion ) & 44.3 & 164.7 & 273.3 & 108.6 \\
\hline Basic savings Deposits A/C through BC's (No. in Million) & 13.3 & 81.3 & 116.9 & 35.7 \\
\hline Basic savings Deposits A/C through BC's (Amt. in Rs. Billion) & 10.7 & 18.2 & 39.0 & 20.7 \\
\hline BSBDAs Total (No. in million) & 0.2 & 4.0 & 5.9 & 2.0 \\
\hline BSBDAs Total (Amt. in Rs. billion) & 55.0 & 182.1 & 243.0 & 60.9 \\
\hline OD Facility availed in BSBDAs (No. in million) & 55.0 & 182.9 & 312.3 & 129.3 \\
\hline OD facility availed in BSBDAs (Amt. in billion) & 0.1 & 1.6 & 16.0 & 14.5 \\
\hline KCCs (No. in million) & 24.3 & 33.8 & 39.9 & 6.2 \\
\hline KCCs (Amt. in Rs. Billion) & 1240.1 & 2423.0 & 3684.5 & 1061.5 \\
\hline GCCs (No. in million) & 1.4 & 3.6 & 7.4 & 3.8 \\
\hline GCCs (Amt. in Rs. Billion) & 35.1 & 76.3 & 1096.9 & 1020.6 \\
\hline ICT A/c's -BC Transaction (No. in million) -During the year & 26.5 & 250.5 & 328.6 & 328.6 \\
\hline ICT A/c's -BC Transaction (Amt. in Rs. billion)-During the year & 6.9 & 233.9 & 524.4 & 524.4 \\
\hline
\end{tabular}

Source: Report on Trend and Progress of Banking in India for the year endedJune 30, 2013 


\section{International Journal of Science and Research (IJSR)}

ISSN (Online): 2319-7064

Index Copernicus Value (2013): 6.14 | Impact Factor (2014): 5.611

\section{Progress of Financial Inclusion in Dakshina Kannada District}

Dakshina Kannada District which is also known as the -Crdle of Banking" has average population of 5000 per Branch. The total number of Banks in the District are 44 Banks (40 Commercial Banks, one RRB, one DCCB, KASCARD and KSFC) having 527 branches. There are 117 PACS having 266 Branches which are affiliated to SCDCC Bank.

\begin{tabular}{|c|c|c|c|c|c|c|}
\hline S. & Agency & $\begin{array}{c}\text { Total } \\
\text { No. }\end{array}$ & \multicolumn{3}{|c|}{ Total number of Branches } \\
\cline { 4 - 7 } & & $\begin{array}{c}\text { Banks } \\
\text { Bamber of }\end{array}$ & Rural & $\begin{array}{c}\text { Semi- } \\
\text { Urban }\end{array}$ & Urban & Total \\
\hline 1 & $\begin{array}{c}\text { Public Sector } \\
\text { Banks }\end{array}$ & 25 & 159 & 87 & 171 & 417 \\
\hline 2 & $\begin{array}{c}\text { Private Sector } \\
\text { Banks }\end{array}$ & 15 & 3 & 16 & 24 & 43 \\
\hline 3 & KVGB (RRB) & 1 & 13 & 5 & 5 & 23 \\
\hline 4 & SCDCC & 1 & 23 & 10 & 5 & 38 \\
\hline 5 & KASCARD & 1 & 0 & 4 & 1 & 5 \\
\hline 6 & KSFC & 1 & 0 & 0 & 1 & 1 \\
\hline & Total & 44 & 198 & 122 & 207 & 527 \\
\hline
\end{tabular}

Source: Lead Bank records

The Growth in the Business of Banks in the District during 2011-12, 2012-13 and 2013-14(Up To 30.06.2013)

\begin{tabular}{|c|c|c|c|c|}
\hline Parameter & \multicolumn{4}{|c|}{ Position as on } \\
\cline { 2 - 5 } & 31.03 .2011 & 31.03 .2012 & 31.03 .2013 & 30.06 .2013 \\
\hline $\begin{array}{c}\text { Aggregate } \\
\text { deposits }\end{array}$ & 1658502 & 2126880 & 2372924 & 2637888 \\
\hline $\begin{array}{c}\text { Aggregate } \\
\text { Advances }\end{array}$ & 941254 & 1107415 & 1340281 & 1419172 \\
\hline $\begin{array}{c}\text { Credit/ Deposit } \\
\text { Ratio }\end{array}$ & 56.80 & 53.50 & 56.48 & 53.80 \\
\hline $\begin{array}{c}\text { Priority Sector } \\
\text { Advances }\end{array}$ & 559121 & 623300 & 840800 & 817000 \\
\hline $\begin{array}{c}\text { Agricultural } \\
\text { Advances }\end{array}$ & 186098 & 229200 & 280700 & 293100 \\
\hline
\end{tabular}

Source: Lead Bank records

Total Priority Sector Advances at Rs.8170 Crore accounted for $58 \%$ of the total advances. Except for DRI advances which stood at $0.01 \%$ of the loans outstanding as on June 30 , 2013, the District has achieved the targets under various subsectors of the Priority Sector. The District is one among those identified as Minority Concentration Districts by the Central Government. Advances to minority communities at Rs. 2072 Crore constituted $25 \%$ of the PSA as against the target of $15 \%$.

Financial Inclusion Strategies

\begin{tabular}{|c|c|c|}
\hline \multirow[t]{2}{*}{ Financial Inclusion Initiatives } & \multicolumn{2}{|c|}{$\begin{array}{c}\text { Progress as on March } \\
31,2013 \\
\end{array}$} \\
\hline & No. & $\begin{array}{c}\text { Outstanding } \\
\text { amount (Rs. in } \\
\text { lakhs) }\end{array}$ \\
\hline No. Frills Account operationalised & 319523 & - \\
\hline Kisan Credit Card (KCC) & 162969 & 154026 \\
\hline General Purpose Credit Card (GCC) & 33781 & 7227 \\
\hline
\end{tabular}

The Bank branches in Dakshina Kannada have issued 77984 $\mathrm{KCC}$ to farmers during the year from 01.04.2013 to 30.06.2013 which includes renewals. The branches have also issued 13807 General Credit Cards (GCCs) amounting to 2761 lakhs as on 30.06.2013.

Self Help Groups as on 31, March 2013, Rupees in lakh

\begin{tabular}{|c|c|}
\hline Total No of SHGs in the District & 59373 \\
\hline Number of women enrolled & 449360 \\
\hline Out of which SC/ST & 22453 \\
\hline Number of SHG completed 6 months & 56170 \\
\hline Number of SHGs graded & 56170 \\
\hline Savings Mobilized & 7949 \\
\hline $\begin{array}{c}\text { Number of SHGs covered under } \\
\text { SGSY during 2012-13 }\end{array}$ & 186 Bank credit- 714.29 \\
\hline $\begin{array}{c}\text { No of SHGs covered under other } \\
\text { schemes during 2012-13 }\end{array}$ & 64 Bank credit- 255.78 \\
\hline
\end{tabular}

Source: Lead Bank records

\section{Bank coverage position as on 30.06.2013:}

All the Unbanked Villages (170) with more than 2000 population are fully covered in the District during the first Phase of Financial Inclusion either by Brick \& Mortar (Branch) or BC Model. During the second Phase of Financial Inclusion, out of 90 Villages with less than 2000 population, Banks in the District have already covered 78 Villages and the remaining Villages will be covered in a phased manner as per the Action Plan submitted to RBI (Source: Lead Bank records).

\section{Financial Literacy and Credit Counselling Centre}

A Trust called Jnana Jyothi Financial Literacy and Credit Counselling Trust (JJFLCC) with Headquarters at Manipal has been formed jointly by Syndicate Bank, Vijaya Bank and Karnataka Bank Ltd. to take up Financial Literacy and Credit Counselling activities by establishing FLCC $\mathrm{s}$ in all the Lead Districts of the sponsor Banks. So far, 18 FLCCs have been opened by JJFLCC Trust in Karnataka. In Dakshina Kannada district, the JJFLCC Trust has 3 FLC centres operating in Mangalore, Bantwal and Belthangady taluks (Source: Lead Bank records).

\section{Suggestions}

In pursuit of financial inclusion, quantity has, however, become the more important factor than the quality. Banks might focus onopening of more and more accounts without really looking into the quality of associated services and perhaps and more often without focusing on the need of raising the awareness levels of the financially excluded Banks need to understand the demand side issues in particular regions, so that appropriate strategies can be implemented. Banks should strive to raise the level of customer service and enhance the awareness for electronic payment system products in pursuit of providing easy \& efficient access to financial services with the aim to move towards a less-cash economy.

Source: Lead Bank records 


\section{Conclusion}

India faces several macro-economic challenges influenced by both global and domestic developments. The Reserve Bank attaches a lot of significance to therole of banks, due to the magnitude of challenges. There is also tremendous scope for thebanks to convert these challenges into opportunitiesfor their sustainable business growth. Banks will havean important role in providing impetus to the domesticgrowth drivers and ease supply constraints.. Qualitative dimensions of financial inclusion also should receiveserious attention of the banks so that efforts made inthis regard result in enduring relationship with thebottom of the pyramid customers and sustainable business proposition for the banks.

\section{References}

[1] Helms, B. Access for all: Building Inclusive financial systems. Consultative Group to Assist the Poor. World Bank. 2006.

[2] Joshi, D.P. 2013. Financial Inclusion: Journey So Far and Road Ahead. Speech delivered at the Mint Conclave on Financial Inclusion, Mumbai on November 28, 2013. RBI Monthly Bulletin December 2013.Pp. 55-62.

[3] Kumar, L., Balasubramanian.G, Economics of the Business Correspondent Model. NSE Working Paper series No. WP 2014-3

[4] Rajput, N., Oberoi,S. Reaching the Unreached: Financial inclusion in India-A Study.

[5] Report on Trend and Progress of Banking in India 201213, Reserve Bank of India.

[6] Narasimhan, C. L. (2014, January 20, Monday). A detailed map for financial inclusion. Business Review, 14.

[7] Singh, A. (n.d.). Challenges: For Building Financial Inclusive India. http://ssrn.com/abstract=1445306.

[8] Vijayalakshmi, D. v. (n.d.). Role of Financial Inclusion for Inclusive Growth in India-issues and challenges.

[9] http://www.microfinancegateway.org/sites/default/files/p ublication_files/larquemin. 